\title{
Factors influencing motivation level of academic staff in Education of IBA Community College, Khairpur Mir's
}

\author{
Dr. Syed Munir Ahmed Shah \\ Associate Professor, Dept. of Business Administration, Shah Abdul Latif University Khairpur Mir's \\ muneer.shah@salu.edu.pk \\ Miss SadafSikandarSamo \\ M.Phil (Scholar),Dept. of Business Administration,Shah Abdul Latif University Khairpur Mir's \\ Sadaf.samo@iba-suk.edu.pk \\ Mr. ShahbazHyder Mughal \\ MS (Scholar), Dept. of Business Administration,Shah Abdul Latif University Khairpur Mir's
} Shehbaz_hyder@hotmail.com

\begin{abstract}
To investigate the degree to which various factors influence motivation level of academic staff of IBA Community College Khairpur Mir's. The study has utilized a questionnaire survey. Participants were 40 (24 male, 16 female) from academic staff.A 21-item questionnaire survey was used that that measured satisfaction level and overall motivation of academic staff. Job satisfaction was measured using five dimensions namely: pay, working conditions, job security, work itself and recognition. To determine its reliability, data was entered in SPSS 16 for checking Cronbach's alpha through correlation analysis then data reduction technique was used to form five factors among all. Two tailed Pearson correlation test was applied for checking the correlation ship among variables.Working condition, recognition and satisfaction level is somehow correlated with work itself. The level of relationship is not too much strong to analyze which factor has high significance and which has low. This study conducted upon college teachers can also be conducted upon university teachers and other sector organizations. The study also declared the factors, which were motivating for the teachers at academic education level. The empirical results from this study would help in describing or clarifying the crucial role of motivation on the needs satisfaction of teachers.
\end{abstract}

Keywords: Motivation; Pay; Recognition; Work itself; Working condition; Job security.

\section{Council for Innovative Research}

Peer Review Research Publishing System

Journal: INTERNATION JOURNAL OF COMPUTERS AND TECHNOLOGY

\author{
Vol. 13, No. 5 \\ editorijctonline@gmail.com \\ www.cirworld.org/journals
}




\section{Introduction}

The teacher can be rightly called a nation builder. No other personality can have an influence more intense than that of a teacher. The achievement of any college depends on high or low motivation of teachers. It is the key of success for any institute. This research study is concentrated on five factors namely, Work itself, working condition, Recognition, job security and pay to examine the motivational level of IBA academician and in this connection, researcher reviewed the research article of Mubbsher\&Hira (2011) as a base paper who conducted the research on factors affecting teacher's motivation. The study has utilized questionnaire to examine IBA's teachers' motivation to address which factors motivate teacher and at what level. This will help education policy maker of IBA Community College KhairpurMir's to recognize the importance of these factors to improve motivational level of academic staff of IBA CC Khairpur Mir's.

\section{Literature Review}

Motivation of teachers is very much essential issue towards their task to communicateinformation and ability to students. Therefore, the effect of motivation is analyzed for the improving performance of primary school teachers in KimaanyaKyabakuza division, Masaka district.Distinctively, it was observed in the study that teacher inspirationperformance is being affected by intrinsic motivation \& extrinsic motivation or not. (Marry, 2005)

The reason that influencemotivation of staffaffiliate of Kotli University has two issues;encouragementand managerialrules were taken as self-governing factors while motivation was taken as conditional factor.This research study was based on quantitative data and wasput forward bysurvey. Fraction, tables and statistics were used to know data. This study suggests that, academic staff motivation is very much affected by administrative policies, whereas incentivize promotes the motivation level. Salary and managerial policies also have negative impact on teacher motivation in university. Few staff members are satisfied with managerial policies and others are not. (ImrabShaheen, 2013)

It can be seen that intrinsic factors tend to motivate the teachers more than extrinsic ones. Through this study, it can be inferred that in education sector, intrinsic sources of motivation are valued more than extrinsic ones. So, in order to increase academician's level of motivation, they must be recognized for their work through promotions, salary raises etc. and must be provided with good and comfortable working conditions. Rewards were measured using five dimensions namely: pay, working conditions, job security, work itself and recognition. Data analysis was done using correlations and regression techniques. Work itself and recognition had statistically strong positive and significant association with motivation of teachers. However weaker relationship was found with working conditions and pay. (Mansoor, March, 2013)

Researcher has used survey research method for data analysis to determine the motivation level of staff.All the staff of the University fully participated in it. Research factors were determined by using arithmeticalapparatus. It was observed that staff members are very much satisfied with working conditions and their performance is also appreciated. Therefore, it was suggested that effective teaching and delivery of knowledge is dependent on motivation of staff. (Mawoli, Dec, 2011)

This researchexercises a survey in 2013 from four faculties and the research was put forward to use regularity and statistics techniques. Teacher satisfaction fully depends on incentives given in their job.Since inspiration is a dynamic construct subsuming various variables that affect a teachers' level of performance, the main aim of this research was to investigate which variables affect teachers' job satisfaction and motivation at the British University in Egypt (BUE). An academics job satisfaction and motivation is a significant factor that will influence the productivity and effectiveness of an institution. Therefore, the results of the present study emphasized the need for higher management, deans and heads of departments to give immediate attention to the extrinsic factors that can result in job satisfaction, so that the university will be able to motivate and retain its academic staff. (Ghenghesh, 2013)

Students learning can be affected by less motivation and dedication of teachers. It is just like to future of students in danger. Teacher plays key role in building career development of students by giving their more efforts. (Kayuni.H. \& Tambulsi, 2007)

There are a lot of factorsthrough which satisfaction of teachers towards work can be decreased. These may be stress, less salary, and issues of colleagues can impact the job performance of teachers. (Nadeem, 2011)

When pay is perfect and given on time to teachers can improve their motivation level.

According to Herzberg motivation hygiene theory that variables related with job are focused properly such as duty and technological growth so it can find better incentives.

No doubt, teacher motivation is basic pillar in building any nation career. (Kazeem, 1999)

Attitude and performance of staff varies organization to organization depending on working conditions and managerial policies that how these are utilizing employee's efforts.Human capital in any education institute can help to put step forward towards success and get their desired outcome. Those great philosopher and scholar were also teachers who brighten their names in history by their well known efforts. (Razzak, 2011).

The distinction in pay can have acontact on agreement of staff which in revolveinfluence their purpose to put honesthard work. The teacher job is very change job in comparison to other jobs just because of teacher role in society. Teachers are likely to be called parents and good fellows. (Volkwein, 2003)

After reviewing it suggests four motivational aspects: intrinsic component, contextual factors, temporal axis and being fragile, that is, being exposed to several powerful negative influences. To satisfy ones need and wants, to motivate the employee to give them real happiness on the job can be treated by intrinsic rewards given to them. (Dörnyei, 2001). 
Besides this, age has been reported to affect the job satisfaction levels of teachers. Researcher has found that academic staff of 56 years or more was more satisfied than those in other age categories. In contrast, Paul \&Phuafound that the satisfaction level plummeted for those aged between 45 to 52 years. In a cross-national study to examine teachers' engagement in five countries: Australia, Canada, China (Hong Kong), Indonesia, and Oman, the results demonstrated a significant but weak correlation between workers ages and engagement.Furthermore, status, that is, the job position/rank has also been reported to affect job satisfaction. In a study conducted at three Malaysian Research Universities, researcher has reported that professors were more satisfied in terms of their overall satisfaction. Moreover, the results revealed that senior staff was not muchpleasedcontrast to less senior teaching staff, but a significant difference only existed between associate professors and professors. (Sadeghi A, 2012)

Researcher has determined the influence of selected motivational factors on the performance of secondary school agriculture teachers in Imenti South District. The study used a cross-sectional research design.

A feedback form was used by the examiner to gather the information from the respondents. Information is analyzed with the help of Statistical Packages of social Sciences (SPSS). It further suggested that the school administrators should equip the availableworkshops with appropriate tools and equipment and in schools without workshops; the administrators should construct them and equip them appropriately to facilitate effective teaching. (Raphael, 2013)

\section{Methodology}

The research article methodology includes studypropose. We have collected data via primary \& secondary sources. A survey was used by us to gather the information from the respondents and know the motivation level of academic staff. Ranking of the questionnaire was found on certain measures ranging from strongly agree to disagree consisting of scores from 1 to 5 . There one represents strongly agree and 5 denotes strongly disagree.A 21 items questionnaire was prepared which was taken in its concludingform after the approval of the supervisor. To determine its reliability, data was entered in SPSS 16 for checking Cronbach's alpha through correlation analysis then data reduction technique was used to form five factors among all. Two tailed Pearson correlation test was applied for checking the correlation ship among variables. From which the value of Cronbach's alpha turned out to be 0.689 .

The study of this research article is based on the factors influencing motivation level of academic staff in education of IBA Community College Khairpur Mir's. The researchlocation is considered relevant because of theperformance of teachers. All academic staff of IBA Community College Khairpur Mir's took active part for the completion of questionnaire surveys and returned to us.

\section{Results and findings}

Table 1: Descriptive statistics

\begin{tabular}{|c||c|c||c||c||c|}
\hline & Salary & $\begin{array}{c}\text { Work } \\
\text { itself }\end{array}$ & $\begin{array}{c}\text { Working } \\
\text { condition }\end{array}$ & Recognition & $\begin{array}{c}\text { Job } \\
\text { Security }\end{array}$ \\
\hline Mean & 2.60 & .000000 & .000000 & .000000 & -6.9388939 \\
\hline $\begin{array}{c}\text { Std. } \\
\text { Deviation }\end{array}$ & 1.297 & 1.000000 & 1.000000 & 1.000000 & 1.000000 \\
\hline $\mathbf{N}$ & 40 & 40 & 40 & 40 & 40 \\
\hline
\end{tabular}

Above given Table 2 shows mean and standard deviation results of the factors influencing motivation level of academic staff of IBA Community College Khairpur Mir's. It can be seen that salary has a mean value of 2.60 which is greater than all others. It indicates that teachers agree salary has an impact on their motivation level. Work itself, working condition and recognition have lower mean values than salary. Job security has negative mean value so it indicates disagree towardswork itself; working condition, and recognition, in last job security also motivate them. 
Table 2: Correlations

\begin{tabular}{|c|c||c|c|c|c||}
\hline & Pay & Work itself & $\begin{array}{c}\text { Working } \\
\text { condition }\end{array}$ & Recognition & Job Security \\
\hline Pay & 1 & $.411^{* *}$ & -.49 & -.131 & .173 \\
\hline $\begin{array}{c}\text { Work } \\
\text { itself }\end{array}$ & $.411^{* *}$ & 1 & $.349^{*}$ & .277 & .017 \\
\hline $\begin{array}{c}\text { Working } \\
\text { Condition }\end{array}$ & -.049 & $.349^{*}$ & 1 & .291 & -.344 \\
\hline \hline Recognition & -.131 & .277 & .291 & 1 & -.228 \\
\hline \hline Job Security & .173 & 0.17 & -.344 & -.228 & 1 \\
\hline
\end{tabular}

All the factors correlation is given in the above table. This research will now be discussed based on the findings of correlation analysis.Here they are having positive and significant relationship with employee motivation. Table 2 showsthecorrelation of five variables given is: pay, work itself, working condition, and recognition and job security. It gives the idea of interpretation and correlation all factors with each other. Hence it is observed from the results that first factor pay has good correlation work itself that is $.411^{* *}$, while correlation of pay with other variables is not good enough. Second factor work itself has good correlation with pay that is again same $.411^{\star *}$ and working condition that is .349*, but do not have better correlation with recognition and job security. Third factor working condition is also not found good in correlation with other factors except work itself that is .349*. Fourth factor recognition has good correlation with work itself that is .277 and working condition that is .291 and no any good relation with other factors. Last factor job security has good correlation with working condition but not found good in correlation with other factors.

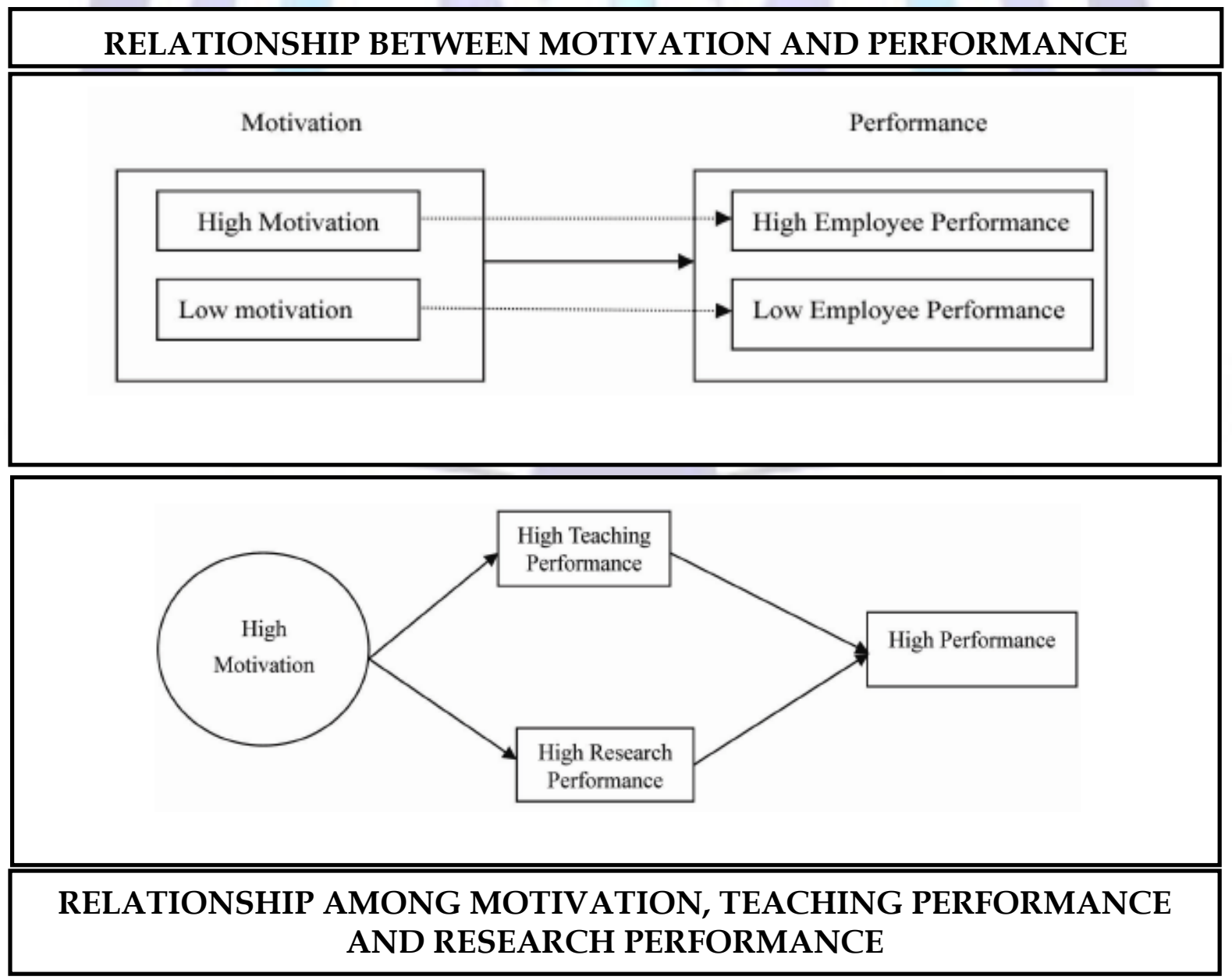


Some of the essential findings and results are given below:

* Work itself is correlated with satisfaction level at current salary.

* Current salary is correlated with satisfaction level at Work itself.

* Recognition is negatively correlated with satisfaction.

* Working condition, recognition and satisfaction level is somehow correlated with work itself.

* Work itself is correlated with working condition \& job security.

* Job security is negative correlated with work itself.

* The level of relationship is not too much strong to analyze which factor has high significance and which has low. On the basis of above result it is clear that workload is too much, teachers are not fully satisfied and motivated at IBA community college. They are doing job only for survival not for recognition or pay.

\section{CONCLUSION}

It is predicted from the research that teaching and research performance can affect the employeeinspiration.

Most of the IBA Community College academicians are not motivated with the administrative policies of their college as pay, work itself, working conditions, and recognition and job security play key role towards motivation of teachers on the job. This may be cause for less satisfaction towards job.

The college teachers have to be sufficiently agreed to make possible usefulawarenessrelease to learners, encourageteaching and resolve the difficulty of waning of teaching. Therefore, the study recommends that IBA Community College Khairpur Mir's and other education institutions should address this issue seriously.

\section{LIMITATIONS \& FUTURE DIRECTIONS}

This research study is conducted on IBA Community College Khairpur Mir's to know and analyze factors influencing motivation level of academic staff in education of IBA CC Khp Mir's. So the views and thoughts of the academician of IBA CC Khp may not have any relation with other teacher's views that limits this research study to only IBA Community College Khairpur Mir's. Teacher's motivation consist of many factors like staffing\&assortmentpractice, guidance, endorsementrules, functioningsurroundings, mutually respectfulthoughts. These should be given importance.

\section{References}

1. Academic Staff level of motivation, dissatisfaction \& Performance at work [Journal] / auth. Mawoli Mohammed Abubakar. - Lapia, Nigeria : [s.n.], Dec, 2011. - Vol. 1.

2. Correlates of job motivation of workers in selected public \& private schools in ife-ijesa zone [Journal] / auth. Kazeem. - Osun state, Nigaria : Obaafemi University Ilfe, Nijaria, 1999.

3. Demographic analysis of on academic staff's job satisfaction [Journal] / auth. Sadeghi A Zaidatol ALP, Habibah E, \& Foo Sf. - Malaysia : Pertanika journal of social sciences \& humanities, 2012.

4. Effects of motivation on the performance of primary school teachers [Journal] / auth. Marry Aacha. - Kyabakuza, Masaka district : [s.n.], 2005.

5. Factors affecting the effectiveness of job performance of specialist working in youth care centre at helwan university [Journal] / auth. Razzak A.A.W. - Helwan university, Helwan : World journal of sport sciences, 2011.

6. Factors affecting the motivation of academic staff (A case study of university college kotli, UAJ \& K) [Journal] / auth. ImrabShaheen Mushtaq.A.Sajid \& QudsiaBatool. - Kotli UAJ \& K : International Journal of Business \& Management Invention, 2013. - 1 : Vol. 2.

7. Influence motivational factors on the performance of teachers [Journal] / auth. Raphael Florence k. kirmi \$. - Imenti south : [s.n.], 2013.

8. Intrinsic Factors tend to motivate the teachers more than extansic ones [Journal] / auth. Mansoor Mubbsher Khan \& Hira Tahir. - March, 2013. - 1 : Vol. 1.

9. Job satisfaction \& Motivation [Journal]/ auth. Ghenghesh Pauline. - Egypt, El Sherouk city : Birtish journal of education, society \& Behavioural science, 2013.

10. Salary impact on satisfaction [Journal] / auth. Volkwein Zhou \&. - 2003.

11. Teacher compentancies \& factors affecting the performance of female teachers [Journal] / auth. Nadeem. Bahawalpur, Pakistan : International journal of Business \& social Science, 2011. - 19 : Vol. 2.

12. Teachers turnover in Malawi's ministry of education [Journal] / auth. Kayuni.H. \& Tambulsi R. - Malawi : Realities \& Challenges international journal, 2007.

13. Teaching \& researching motivation [Journal] / auth. Dörnyei. - Harlow, longman : Oxford Blackwell, 2001. 


\section{Author's Biography}

"Passed his MPA From Quaid e lazam University Islamabad Pakistan and appointed as lecturer in the department of Business Administration Shah Abdul Latif University Khairpur, completed his M. Phil from there and Promoted as Assistant Professor, than completed his Ph. D in HRM from IQRA University Karachi and again appointed as Associate professor in the department of Business Administration SALU Khairpur, Sindh Pakistan". 